\title{
Development of Realistic Mathematics Education-Based Learning Devices to Improve Mathematical Problem Solving Skills of SMP Negeri 1 Medan Students
}

\author{
Else Frine Tamba*, Syafari, Pargaulan Siagian, Meytri Laurence Sihotang \\ Post Graduate Program in Mathematics Education, State University of Medan, Medan, Indonesia \\ *Corresponding author: elsefrine.tamba89@gmail.com \\ Received October 10, 2018; Revised November 29, 2018; Accepted January 01, 2019
}

\begin{abstract}
The objectives of this study are to describe: 1) validity of learning tools developed based on the Realistic Mathematics Education approach; 2) practicality of learning tools developed based on the Realistic Mathematics Education approach; 3) the effectiveness of learning tools developed based on the Realistic Mathematics Education approach; 4) improvement of students' mathematical problem solving skills using learning tools based on the Realistic Mathematics Education approach that has been developed. This research is a development research. The development model used to develop learning tools in this study is the Dick and Carey development model. Before the field trial was conducted, the learning tools were validated by three experts and two practitioners. From the results of the validation, it was found that: (1) the learning tools developed were valid with the total average validity of student books (4.33), teacher books (4.28), learning implementation plans (4.42), and student worksheets (4.44). Subjects in this study were seventh grade students of senior high school (SMP) 1 Medan which consisted of two classes, namely VII-Herodotus as a trial class I and VII-Pythagoras as a trial class II. (2) learning tools that had been developed are effective, seen from classical learning completeness are fulfilled, in which $\geq 85 \%$ of students were passed, student activities within the specified tolerance limits, and students' responses to learning are in good categories; (3) the average increase in students' mathematical problem solving ability from trial I to trial II was 0.18 points, namely from 3.02 in the first trial to 3.20 in the second trial, with an increase in classical mastery learning $14 \%$.
\end{abstract}

Keywords: development of learning tools, Dick and Carey model, realistic mathematics education approach, problem solving mathematics

Cite This Article: Else Frine Tamba, Syafari, Pargaulan Siagian, and Meytri Laurence Sihotang, "Development of Realistic Mathematics Education-Based Learning Devices to Improve Mathematical Problem Solving Skills of SMP Negeri 1 Medan Students.” American Journal of Educational Research, vol. 7, no. 1 (2019): 1-5. doi: 10.12691/education-7-1-1.

\section{Introduction}

An advanced nation is a nation that has quality of human resources (HR), both in terms of spiritual, intelligence and skills. To create the quality of human resources, the quality of education is needed as well. Education is closely related to the learning held in schools. Therefore the quality of good education will affect good learning in schools especially learning mathematics. Observing the importance of the role of mathematics in human life, it is natural that students in schools are required to understand mathematics, and are proficient in various mathematical representations and problem solving.

Mathematics is an important subject to be taught at every level of education because it provides many benefits including helping to prepare for a career in the future, building problem solving skills, forming character, helping to learn other knowledge, forming a logical mindset, advancing ways of thinking so that students can have the ability to obtain, manage, and utilize information to survive in a state that is always changing, uncertain, and competitive [1].

Director of Education and Culture Ministry [2] stated that things that need to be developed in mathematics learning are 1) mastery of mathematical concepts; 2) problem solving skills; 3) the ability to reason and communicate; 4) the ability to think creatively and innovatively. Mastery of mathematics plays an important role for students to face the challenges of the future with sophisticated technology at this time, so that individuals are required to have various abilities. This causes humans to be required to improve the quality of education, especially in the field of mathematics.

But in reality Indonesian mathematical abilities are still low. This can be seen from the results of a study conducted by the 2015 Program for International Student Assessment (PISA), Indonesia ranked 62 of 70 participating countries with an average score of 386 [3]. 
One of the factors that can cause low mathematical students' ability to solve is that students tend to be passive, mostly working on routine problems and not understanding what is meant by the problem they face. In addition, in learning mathematics teachers must use strategies that can improve mathematical problem solving skills in students.

The importance of problem solving ability by students in mathematics is stated by Branca [4] as follows: (1) problem solving ability is a general goal of teaching mathematics, even as the core of mathematics; (2) problem solving includes methods, procedures, and strategies are core and main processes in the mathematics curriculum; and (3) problem solving is a basic ability in learning mathematics. The same thing also said [5] that mathematical problem solving has long been seen as an important aspect of mathematics, teaching mathematics, and learning mathematics.

According to Pamungkas and Masduki [6] the ability to solve mathematical problems is the ability that must be possessed by students to be able to understand problems, plan solutions, solve problems, and re-examine the results of a given mathematical problem. So, developing problem solving skills is one of the objectives of learning mathematics that is considered important.

Besides problem solving abilities, there are several things that need to be improved in the education system, namely the development of learning tools, teacher empowerment and the development of learning models used in schools. Among those things mentioned above, the development of learning tools is very important to improve the quality of education, especially mathematics lessons in schools. Every teacher in the education unit is obliged to prepare learning tools in a complete and systematic manner so that learning takes place interactively [7]. According to Ritonga [8] The learning device is one manifestation of the preparations made by the teacher before making the learning process. Learning tools which have certain qualities provide convenience to the teachers and can assist them in preparing and carrying out teaching and learning activities in the classroom, so that the teaching materials used enable students to learn mathematics easily [9].

In an effort to improve mathematical problem-solving abilities of students, an approach that can improve students' problem solving abilities in learning mathematics is needed. One of the mathematical approaches that are oriented towards mathematical everyday experience and applying mathematics in daily life is the Realistic Mathematics Education (RME) approach.

\section{Materials and Methods}

Mathematical problems which become challenges nowadays need solution and require creativity, understanding, and original thought or imagination. Problem solving is the ability that can be found in each person in which the solution varies depending on what they see, observe, remember and think in accordance with real life events.

The importance of mathematical problem solving abilities possessed by students: (1) the ability to complete is a general goal of teaching mathematics, even as the core of mathematics; (2) problem solving includes methods, procedures and strategies are the core and main processes in the mathematics curriculum; and (3) the completion of mathematics is a basic ability in learning mathematics. [10] reveals the advantages of problem solving abilities, namely when solving problems, students learn to apply their mathematical skills in new ways, develop a more understanding of mathematical ideas and get a sense of experience "Being a mathematician".

Campione, Brown and Connel [11] provide three stages of assessment to measure the progress of problem solving activities. First, understanding the problem; whether important information and ideas in the problem are known. Second, the representation; whether they have been able to make external representations of problems that make it easier for them to handle the problems. Third, the solution; whether the chosen strategy is correct and accurate.

\subsection{Realistic Mathematics Education Approach}

According to Sunadi [12] Realistic Mathematics Education is a method of learning school mathematics carried out by placing the reality and experience of students as the starting point of learning. Furthermore, students are given the opportunity to replicate mathematical concepts to solve everyday problems or in other fields. According to Saleh [13] Realistic Mathematics Education is an approach that can help teachers carry out the learning process that brings students into the context of the real world, so that students have a "quality" impression because students experience directly in discovering the mathematical concepts they face and learn.

So from the various opinions above, it can be concluded that the Realistic Mathematics Education Approach is an approach to learning mathematics that starts from the "real" things for students, and provides direct experience for students in finding mathematical concepts.

\subsection{Development of Learning Devices}

Learning devices are a set of learning resources that allow students and teachers to carry out learning activities. They will help and facilitate the process of learning in order to achieve the stated goals. Learning tools become a guide for teachers in carrying out learning both in class, laboratory or outside the classroom. [14] states that learning devices are devices used in the learning process. The function of learning devices is to provide direction for the implementation of learning so that it becomes directed and efficient. According to Yustianingsih [15] the success of students in learning mathematics, is not only determined by the students' interest in the way the teacher teaches, but can also be determined by the way the teacher of the particular subject packs the learning device, because the learning device serves as guidance to the learning process in achieving the objectives of the learning.

According to Simanungkalit [16] learning tools are one form of preparation carried out by the teacher before they conduct the learning process. Hidayat [17] suggests that the tools that must be prepared in planning learning include: understanding the curriculum, mastering teaching materials, arranging teaching programs, implementing teaching programs and assessing teaching programs and 
the results of teaching and learning processes that have been implemented.

The devices used in the learning process are called learning devices. Learning tools that are needed in managing the teaching and learning process can be: syllabus, Learning Implementation Plan (RPP), Student Activity Sheet (LKS), Learning Outcomes Evaluation or Test Instrument (THB), learning media, and student textbooks.

\subsection{Research Methodology}

The type of this study is Research and Development. In this study, researchers developed learning tools with realistic mathematical approaches. Subjects in this study were students of SMP Negeri 1 Medan Class VII-Herodotus and VIIPythagoras with each number of students 36 people in the academic year 2018/2019. The object in this study is a mathematical learning device with social arithmetic.

This study is the development of learning tools which include (1) teacher books; (2) student books, learning implementation plans (RPP); (3) student activity sheet (LAS); (4) test instruments for problem solving abilities. The model of learning device development carried out is the Dick and Carey model.

The quality of learning devices is measured based on: (1) validity, namely the extent to which a tool is able to measure what people think should be measured by the tool with validity criteria $4 \leq \mathrm{Vt}<5$ (valid); (2) and measuring the effectiveness of learning devices seen from four aspects, namely: completeness of learning achievement, student response, student activity, improvement of students' mathematical problem solving abilities; (3) the practicality of learning devices seen from the teacher and student interview sheets, the observation sheet on the implementation of learning. And to see the improvement of students' mathematical problem solving abilities classically obtained from the comparison of the results of the posttet test trial I with the posttest trial II.

\section{Result}

\subsection{The Validity of Learning Device}

Based on the results of the validation of experts and practitioners regarding Teacher Books, Student Books, RPP, LAS, and Ability Tests Problem solving meets the "valid" category so that learning tools can be used with minor revisions given by experts.

Table 1. Summary of Learning Device Validation Results

\begin{tabular}{|c|c|c|c|}
\hline No. & Object Assesssed & $\begin{array}{c}\text { Nilai rata-rata } \\
\text { total validitas }\end{array}$ & $\begin{array}{c}\text { Tingkat } \\
\text { Validasi }\end{array}$ \\
\hline 1. & Teacher Book (BG) & 4.28 & Valid \\
\hline 2. & Student Book (BS) & 4.33 & Valid \\
\hline 3. & Learning Implementation Plan (RPP) & 4.42 & Valid \\
\hline 4. & Student Acticvity Sheets (LAS) & 4.44 & Valid \\
\hline
\end{tabular}

Validity criteria as follow:

$$
\begin{array}{ll}
1 \leq V_{a}<2 & \text { Invalid } \\
2 \leq V_{a}<3 & \text { Less valid }
\end{array}
$$

$$
\begin{array}{ll}
3 \leq V_{a}<4 & \text { Quite valid } \\
4 \leq V_{a}<5 & \text { Valid } \\
V_{a}=5 & \text { Very valid }
\end{array}
$$

Based on Table 1 above, the average validity of each learning device is at an interval $4 \leq V_{a}<5$ valid. Based on the validity criteria, it can be said that this learning device is valid.

\subsection{The Effectiveness of Learning Device}

Effective device criteria can be seen from the achievement of student learning completeness. The classical completeness of student learning on trial I and trial II can be seen in Table 2 .

Table 2. Percentage of Student Classical Completeness

\begin{tabular}{|c|c|c|c|}
\hline \multirow{2}{*}{ Remark } & \multicolumn{2}{|c|}{ Trial } & \multirow{2}{*}{ Progress } \\
\cline { 2 - 3 } & I & II & \\
\hline Average & 3,02 & 3,20 & 0.18 \\
\hline Percentage of students completed (\%) & $75 \%$ & $89 \%$ & $14 \%$ \\
\hline Percentage of students incompleted (\%) & $25 \%$ & $11 \%$ & \\
\hline
\end{tabular}

From Table 2 it can be seen that the average students' mathematical problem solving ability in the first trial was 3.02 and the second trial was 3.20 thus an increase was 0.18 . And an increase in the percentage of classical completeness of students from the first trial was $75 \%$ and the second trial was 89 with a classical improvement of $14 \%$. For more details can be seen in the following diagram.

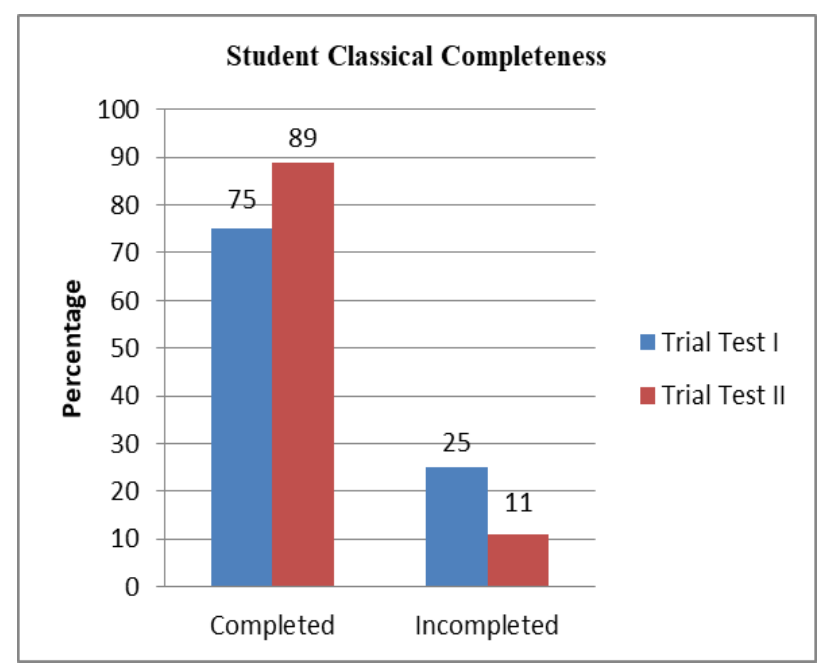

Figure 1. Classical Student Completness

The second effectiveness criterion was seen from the average percentage of student activity for each category in the trial I was $20.54 \%$ for first meeting; the second meeting was $17.05 \%$; the third meeting was $34.29 \%$; the fourth meeting was 26.49\%; and the fifth meeting was $1.68 \%$. Whereas in the second trial the average percentage of student activity for each category in the first meeting of trial II was $21.43 \%$; the second meeting was $18.64 \%$; the third meeting amounted to $29.23 \%$; the fourth meeting was $31.86 \%$; and the fifth meeting was $1.23 \%$. The results of student analysis and activity show that the percentage 
of time of this activity is at the specified ideal time tolerance interval. If it refers to the specified criteria, student activity is effective.

The third effectiveness criterion was seen from the students' positive response to the components and learning activities. The instrument used to determine student responses was questionnaire. From the results of the first trial questionnaire obtained an average of $85.59 \%$ of the number of students in class VII-Herodotus gave a positive response to the learning devices developed. Whereas in the second trial, the average percentage of students who gave positive response towards learning devices developed was $90.98 \%$. If the results of this analysis are referred to the specified criteria, it can be concluded that the students' response to the developed learning device is positive. If referring to the criteria of effectiveness that the learning device developed has been effective.

\subsection{Practicality of Learning Devices}

The practicality aspect of this learning device is seen whether students and teachers as users can use these tools easily. Data obtained based on the results of interviews with teachers and students involved in the use of developed learning tools. Based on the results of the interviews, the responses of teachers and students to the learning tools developed were very positive. This shows that students and teachers consider learning tools used are practical.

The practical aspect is also seen from the implementation of the learning tool, the average percentage of observations of the implementation of the learning device for the first trial is 80.54 in the good category. And in the trial II the presentation of learning 85.28 is also in the good category, namely ( $80<k<90)$. Thus it can be concluded that, the learning tools developed are practical. For more details, the implementation table can be seen in the following table.

Table 3. The Implementation of Learning Devices

\begin{tabular}{|c|c|c|c|c|c|}
\hline \multirow{2}{*}{$\begin{array}{c}\text { The avarage of two } \\
\text { observers }\end{array}$} & \multicolumn{4}{|c|}{ Meeting } & \multirow{2}{*}{$\begin{array}{c}\text { Final } \\
\text { average }\end{array}$} \\
\cline { 2 - 5 } & $\mathbf{1}$ & $\mathbf{2}$ & $\mathbf{3}$ & $\mathbf{4}$ & 80,5 \\
\hline Trial Test I & 80,0 & 78,8 & 81,1 & 82,2 & 85,3 \\
\hline Trial Test II & 84,4 & 86,7 & 83,3 & 86,7 & 85,3 \\
\hline
\end{tabular}

\subsection{Increasing Students' Mathematical Problem Solving Ability}

After conducting the trial twice, the data obtained in both trials were analyzed to see the results of the improvement of each indicator in solving student problems with a device developed based on Realistic Mathematics Education. The improvement of students' mathematical problem solving skills can be seen from the improvement of each indicator in trial 1 and trial II. There was a significant improvent of students' mathematical problem solving skills after conducting the second trial test. For more details can be seen in the following table.
Table 4. Result of Students' Mathematical Problem Solving Improvement in Each Indicator

\begin{tabular}{|l|c|c|c|}
\hline \multirow{2}{*}{ Indicator } & \multicolumn{2}{|c|}{ Posttest Trial Test I } & \multirow{2}{*}{ Improvement } \\
\cline { 2 - 3 } & I & II & \\
\hline Understanding the problem & 2,59 & 2,59 & - \\
\hline Planning the problem solving & 2,44 & 2,64 & 0,20 \\
\hline $\begin{array}{l}\text { Implementing the problem } \\
\text { solving skill }\end{array}$ & 2,55 & 2,77 & 0,22 \\
\hline
\end{tabular}

From Table 4 it shows that the improvement of mathematical problem solving from trial I to trial II for the first indicator does not exist, for the second indicator is 0.20 , and the third indicator is 0.22 . So it can be concluded that the tools of realistic mathematics-based learning can improve students' mathematical problem solving.

\section{Discussion}

The results of the analysis of the data obtained from the research in the first trial and the second trial showed: (1) the developed realistic mathematics education based learning was valid; (2) a realistic mathematics education based learning tool developed was effective; (3) a practical mathematics education based learning tool developed was practical; (4) there is an improvement in problem solving developed based on realistic mathematics education.

The results of this study were strengthened by Adek [18] on his study entitled Impact of Indonesian Realistic Mathematics Approach to Students Mathematic Disposition on Chapter Two Composition Function and Invers Fungtion in Grade XI IA-1 SMA Negeri 4 Padangsidimpuan. stated that Students are more active in the learning process by using RME than without using RME (traditional approach) Mathematic disposition in class XI IA SMA Negeri 4 Padangsidimpuan.increase after using RME. It shown from the average score comparation from pre-test and post-test. Average before RME 70.00 and after RME 78.95 Hypothesis result shown that the application of RME for students mathematic disposition are better after using RME, means, there are significant influences in applying RME to students mathematic disposition class XI IA SMA Negeri 4 Padangsidimpuan.

Muchayat [19], in his journal about the development of mathematical learning devices with ideal problem solving strategies charged with catholic education shows that the products developed can improve students' problem solving abilities. This can be seen from the learning outcomes of students who use products with ideal problem solving strategies better than student learning outcomes in conventional groups. So that it can be concluded that the problem-based learning device developed can improve students' problem solving abilities.

\section{Conclusion}

Based on the results of data analysis and research results, the conclusions which are the answers to the proposed research questions are: 
1. The validity of developed learning devices is in the valid category.

2. The effectiveness of learning devices meets effective criteria. It can be seen from: (1) Achievement of student learning completeness with a percentage of classical completeness of 89\%; (2) The active activity of students fulfills the criteria for tolerance of the ideal time set; (3) Students' responses to learning devices are in good category.

3. Practicality of learning devices seen based on the results of teacher and student interviews is stated practical. And practicality aspect is also seen from the implementation of learning tools. The average percentage of observations of the implementation of learning devices is in the good category.

4. The average improvement of students' mathematical problem solving ability from trial I to trial II is 0.18 points with an increase in mastery learning classically by $14 \%$.

\section{References}

[1] Novrini, Siagian,P., and Surya E. 2015. Development of Learning Tools Oriented Problem Based Learning to Improve Visual Thinking Ability in Solving Mathematical Problems of Grade VII SMP. Vol 8. No. 3 hal 84.

[2] Permendikbud RI. 2013. Salinan Lampiran Permendikbud No. 65Tahun 2013 tentang Standar Proses.

[3] OECD (2015) PISA 2015. Mathematics Framework: Draft Subject to Possible revision after the Field Trial.

[4] Syaiful. 2012. Peningkatan Kemampuan Pemecahan Masalah Matematis Melalui Pendekatan Pendidikan Matematika Realistik. Edumatica Volume 02 Nomor 01, April.

[5] Liljedahl, P., Santos, M., Malaspina, T.U., \& Bruder, R. 2016. Problem Solving in Mathematics Education. ICME-13 Topical Surveys. Germany: Springer Open.

[6] Pamungkas, M.D., \&Masduki. 2013. Improved Ability to Solve Problems and Creativity in Learning Mathematics by Using Core Math Tools (CMT) Software: Seminar Nasional Pendidikan Matematika Surakarta, 15 Mei 2013.

[7] Siagian, P., Simanjuntak, E.,and Samosir, K 2016, Prototype Pembelajaran Matematika Sma Sesuai Kurikulum 2013 Untuk Meningkatkan Kemampuan Pemecahan Masalah Di Provinsi
Sumatera Utara. Jurnal Penelltlan Bldang Pendldlkan. Volume 22 (2): 91-108, 2016

[8] Ritonga, E,. Surya, E and Syahputra E. 2017. Development of Learning Devices Oriented Model Eliciting Activities to Improve Mathematical Problem Solving Ability Junior High School Students. International Journal of Sciences: Basic and Applied Research. Vol. 33, No. 3, pp. 42-52.

[9] Sulistyaningsih, Erly. 2013. Development of ICT-Based Mathematics Teaching Materials in the JJIGSAW Learning Model Differential Material. MIPA Faculty. IKIP Semarang

[10] Shapiro, Sharon. 2011. Badger Maths Problem Solving: Skill and strategies for practical problem solving. Great Britain: Badger Publishing.

[11] Napitupulu, E.E \& Mansyur, A. (2011). Kemampuan Pemecahan Masalah Matematika Siswa (Studi Kasus di SMA Negeri Parongpong Kabupaten Bandung Barat). Jurnal Generasi Kampus Vol. 4 No. 1, issn 1978-869X.

[12] Sunadi. 2014. Pembelajaran Matematika Realistik Untuk Meningkatkan Kemampuan Komunikasi Matematika Siswa. Prosiding Seminar Nasional Pendidikan Matematika Program Pascasarjana STKIP Siliwangi Bandung.Volume 1.

[13] Saleh, M. 2012. Pembelajaran Kooperatif Dengan Pendekatan Pendidikan Matematika Realistic (PMR). Jurnal Pendidikan Serambi Ilmu, Edisi September 2012, Volume 13 Nomor 2.

[14] Trianto.2013. Mendesain Model Pembelajaran Inovatif-Progresif. Jakarta: Kencana 2010.

[15] Yustianingsih, R., Syarifuddin, H., dan Yerizon. 2017. Development of Mathematics Learning Tools Based on Problem Based Learning (Pbl) to Improve Problem Solving Ability of Class VIII Students, JNPM Journal (National Journal of Mathematics Education)Vol. 1, No. 2, Hal. 258-274 p-ISSN 2549-8495, e-ISSN 2549-4937.

[16] Simanungkalit, 2016. Development of Learning Devices to Improve the Mathematical Problem Solving Ability of Public Elementary School Students 12 in Pematangsiantar. Journal of Mathematics Education, Science and Technology Vol. 1, No. 1. Hal 39-56.

[17] Majid, A. 2012. Learning Planning Developing Teacher Competency Standards.. Bandung : PT Remaja Ros dakarya.

[18] Adek, S., Surya, E., Syahputra, E. \&Simbolon, M. 2017. Impact of Indonesian Realistic Mathematics Approach to Students Mathematic Disposition on Chapter Two Composition Function and Invers Fungtion in Grade XI IA-1 SMA Negeri 4 PadangsidimpuanInternational Journal of Novel Research in Education and Learning Vol. 4, Issue 2, pp: (93-100).

[19] Muchayat, 2011.Development of Mathematics Learning Devices with Ideal Problem Solving Strategies with Character Education. Jurnal PP Volume 1, No. 2, Desember. ISSN 2089-3639. 